\title{
Drivers of Globalization of R\&D Investment by U.S. Multinational Enterprises: Evidence from Industry-Level Data
}

\author{
Yixiao Zhou ${ }^{1}$ \\ ${ }^{1}$ School of Economics and Finance, Curtin University, Perth, Australia \\ Correspondence: Yixiao Zhou, School of Economics and Finance, Curtin University, Bentley, Perth, WA, 6004, \\ Australia. Tel: 61-8-9266-7305. E-mail: yixiao.zhou@ curtin.edu.au
}

Received: December 3, 2015

Accepted: January 5, $2015 \quad$ Online Published: January 25, 2016

doi:10.5539/ijef.v8n2p51

URL: http://dx.doi.org/10.5539/ijef.v8n2p51

\begin{abstract}
Existing country-level and firm-level studies have shed light on the mechanisms driving the globalization of R\&D investment by multinational enterprises. However, there is a lack of industry-level evidence on this issue, which is much needed for the robustness of the theoretical and conceptual framework developed from countryand firm-level studies. Therefore, this study examines the determinants of overseas R\&D investment by multinational enterprises from a single country, the United States, using an industry-level panel dataset. This study covers U.S. multinational enterprises in seven two-digit-level North American Industry Classification System (NAICS) manufacturing industries in twenty-three countries over the period 1999-2008.

The empirical findings suggest that technology-seeking motive, technology-adaptation motive, and access to an abundant pool of researchers exert positive impact on the R\&D intensity of U.S.-based multinational enterprises in a host country. The roles of investment position, institutional quality and distance are not found to be robust. These findings are largely consistent with the current theoretical understanding on R\&D globalization by multinational enterprises. The findings point to the need for policies that strengthen domestic R\&D stock, enhance human capital endowment and support a domestic market that is open to the world in order to attract overseas R\&D investment by multinational enterprises.
\end{abstract}

Keywords: globalization, industry-level data, R\&D investment, system GMM estimation, U.S.-based multinational enterprises

\section{Introduction}

Multinational enterprises (MNEs) are constantly looking for the most favourable conditions for the internationalisation of their activities along the value chain. Activities that were previously locally integrated and concentrated have increasingly been relocated to other countries, and $R \& D$ is undoubtedly one of them (Kaplinsky, 2000; Hummels et al., 2001; Hanson et al., 2005; Fujita \& Thisse, 2006; Helpman, 2006; Roper et al., 2008; Lewin et al., 2009; Rugman et al., 2011; Castelli \& Castellani, 2013). Consequently, we observe deepening of globalization of R\&D by MNEs (European Commission, 2011, 2013, 2014). According to the World Intellectual Property Report (2011), annual overseas R\&D investment by U.S.-based MNEs increased from around USD 600 million in 1966 to USD 28.5 billion in 2006. In terms of absolute amount, high-income countries are still dominant locations of R\&D activities by U.S.-based MNEs, accounting for about $80 \%$ of total overseas R\&D investment. In terms of the increase in the share in global R\&D, however, some high-performing East Asian economies, such as China, Malaysia, the Republic of Korea and Singapore, and also India, have experienced the most rapid growth in recent years.

Not only has the geographical spread of MNEs' R\&D investment become much wider, the importance of MNEs in global R\&D investment has grown as well. MNEs are responsible for a large and growing share of global R\&D activities. In 2013, the world top 2500 R\&D investors, which account for about $90 \%$ of global industrial R\&D, continued to increase their investment in R\&D by $4.9 \%$ to EUR 538.3 billion (European Commission, 2014). Inward R\&D-intensive foreign direct investment (FDI) is a powerful mechanism for international technology transfer and a key source of high-quality jobs, and enables host locations to integrate more advantageously into global value chains. Globalization of $R \& D$ by multinational enterprises creates an opportunity for countries below the world technology frontier to utilise this international source of knowledge (Carlsson, 2006; Saliola \& Zanfei, 2009; Qu et al., 2013). Therefore, competition among governments for MNEs' 
internationally allocated R\&D resources has grown significantly (Mudambi \& Mudambi, 2005; Zanatta et al., 2006; Guimón, 2009; Guimón \& Filippov, 2012).

Against this backdrop, scholars have embarked on a quest to identify the drivers of overseas R\&D investment by MNEs. Up until now, country- and firm-level studies have enriched our understanding on the determinants of the location of R\&D investment by MNEs (Feinberg \& Gupta, 2004; Hedge \& Hicks, 2008; Athukorala \& Kohpaiboonb, 2010; European Commission, 2015; Haakonsso \& Ujjual, 2015; Laurens et al., 2015). Country-level studies have captured the importance of economy-wide variables such as domestic technological capability and domestic market size. Athukorala and Kohpaiboonb (2010), using country-level data, find that the R\&D intensity of operations of U.S.-based MNE affiliates is determined mainly by domestic market size, overall R\&D capability, and the cost of hiring R\&D personnel. The firm-level study by Feinberg and Gupta (2004) uses individual firm-level data to explore the determinants of overseas R\&D investment by U.S.-based MNEs, and include firm-level operating variables that influence firm's absorptive capacity of external knowledge in the analysis. Haakonsso and Ujjual (2015) investigate the dynamics and strategies of R\&D internationalization through an in-depth case study of a biomedical multinational enterprise. Laurens et al. (2015) examine the changing relative importance of market-seeking motive and technology-seeking motive using patent data large multinational firms.

In contrast with the amount of evidence from country-level and firm-level studies, there is a lack of industry-level studies on the R\&D globalization by MNEs. An industry-level study could significantly complement our understanding on the issue for the following reasons. Firstly, when trying to measure the technology-seeking motive of MNEs, country-level studies adopt aggregate country-level R\&D variables such as $\mathrm{R} \& \mathrm{D}$ expenditure as a share of GDP and the number of patents normalised by the population size to reflect the domestic technological capability of a host country. However, as suggested by Cantwell et al. (2004), Hansen and Lovas (2004) and Dosso and Vezzani (2015), it is important to focus on firms in the same industry because knowledge spill-overs that are closely related to MNE's own knowledge base are more useful than less related knowledge. Using industry-level data, we make direct observation of the technological capability of the relevant industry and country where a multinational enterprise operates. Therefore, the results in this study complement country-level studies in answering whether the technology-seeking motive is a driver of R\&D investment by MNEs. Secondly, firm-level study by Feinberg and Gupta (2004) uses country dummies to proxy for the effects of economy-wide factors such as institutional quality and abundance of researchers. The impact of these variables is of high policy interest since government policies could help adjust these economy-wide factors. However, values of these variables may change over time and could not be captured by country dummies. Therefore, this study takes into account changes of these economy-wide factors by using time-varying measures of these factors.

To preview the empirical analysis, this study uses a panel dataset of overseas R\&D investment by U.S.-based MNEs during 1999-2008, constructed at the two-digit level of NAICS. Since the U.S. is one of the countries on the world technology frontier, clarifying what drives the R\&D investment of U.S.-based MNEs helps countries formulate effective policies to attract $R \& D$ investment of MNEs from other advanced countries as well. The paper is organised as follows. Section 2 provides a brief review of the current theoretical understanding about overseas R\&D activities of MNEs. Section 3 examines the trends and patterns of R\&D expenditure of U.S.-based MNEs. Section 4 presents the empirical specification and the econometric method. Section 5 reports and interprets the results of the baseline regression analysis and those of robustness checks. Section 6 concludes and summarizes the implications of the findings.

\section{Motives and Determinants of Overseas R\&D Investment}

In this section, we first discuss the motives for MNEs' overseas R\&D activities. We then examine the determinants of overseas R\&D activities by MNEs. Both the motives and determinants will affect the outcome of MNEs' overseas R\&D investment and will be incorporated in the regression analysis in Section 4.

Research on R\&D globalization identifies two sets of motives from an MNE's perspective for overseas R\&D investment. The first stems from the technology-seeking hypothesis, which argues that MNEs tries to capture knowledge internationally (Kuemmerle, 1999; Patel \& Vega, 1999; Von Zedtwitz \& Gassmann, 2002; Cantwell \& Mudambi, 2005; Iammarino \& McCann, 2013; Castelli \& Castellani, 2013). In order to remain at the global competitive edge, MNEs need to tap into various centers of knowledge and R\&D around the world to renew their knowledge base and sustain their technological leadership. Globalization of R\&D activities is a conscious strategy of technology-seeking MNEs that try to locate their R\&D activities in a host country having an advantage in a certain area of technology, and to benefit from globally-dispersed reservoirs of knowledge (Jaffe 
et al., 1993; Audretsch \& Feldman, 1996; Branstetter, 2001; Keller, 2002; Von Zedtwitz \& Gassman, 2002; Branstetter et al., 2006; Belderbos et al., 2008; Griffith et al., 2008; Shimizutani \& Todo, 2008; Zhao \& Liu, 2008). New knowledge sourced from a host country helps develop technologies and products that serve, not only the host market, but also the home and the global ones (Cantwell \& Mudambi 2005; Ambos et al., 2006).

Research has shown that MNEs with overseas R\&D subsidiaries use technology from foreign scientific communities more effectively and enjoy more inventive activities (Iwasa \& Odagiri, 2004; Penner-Hahn \& Shaver 2005; Naghavi \& Ottabiano, 2009). Increasing the number of FDI projects in R\&D makes an MNE's entrance in the top R\&D circle more probable and also reduces the probability of exiting from the circles. R\&D internationalization provides companies with a sustainable competitive advantage in the race for the most substantial R\&D investments and R\&D global leadership and for the entailed economic and financial benefits (Montresor \& Vezzani, 2015).

The second motive stems from the technology-adaptation hypothesis. According to this hypothesis, R\&D conducted by foreign affiliates can focus on the adaptation of home-developed technologies to respond to demand needs and consumer preference in foreign markets and thus increase sales in these markets (Dunning, 1993). This type of R\&D focuses on the exploitation and application of an MNE's home-based capabilities and technologies in a host country. According to Athukorala and Kohpaiboon (2010), there are two elements to this hypothesis: distance and host country's market size. Longer distance of the host country from the home country can either increase or decrease the R\&D intensity of affiliates of MNEs. Longer distance may intensify the need to conduct R\&D for adaptation to the local market that has a different environment from home market. However, it may also increase market segregation, which increases the cost of FDI and hence decreases R\&D investment of affiliates of MNEs since overseas R\&D investment is part of FDI by MNEs. The impact of host country's market size on MNEs' local R\&D effort can go either way as well. On the other hand, when MNE affiliates serve mostly the host market, i.e. when the host country is relatively large, the affiliates may be faced with specific demands for product features and technological inputs from the host country, and therefore need more technology adaptation and R\&D effort. In this case, an affiliate located in a large host country market may have high R\&D intensity (Kumar, 1996). On the one hand, if MNE affiliates located in a host country produce for wider regional or global markets in addition to serving the host market, that is if the host market is relatively small, the MNE affiliates may feature a high R\&D intensity because they conduct R\&D activities to serve wider markets.

Human capital and institutional quality in a host country are two potential determinants of overseas R\&D investment by MNEs since they are critical components of the investment environment for R\&D activities. The attractiveness of a given country as a location for R\&D activities may depend on how well the country meets the human capital requirements for undertaking R\&D activities. MNEs favour countries endowed with a higher proportion of scientists, engineers or higher education graduates (Dosso \& Vezzani, 2015). Institutional quality may also matter if one views firm R\&D decisions as responses to the "rules of the game in society" that structure incentives in economic activities (North, 1991; Tebaldi \& Elmslie, 2008). As basic rules in a market economy, institutions such as property rights (including intellectual property rights, i.e. IPR) protection and the effectiveness of contract enforcement affect corporate incentives for investments of all kinds, both in tangible and intangible assets. Guimón (2013) points out that developing countries tend to have weaker IP regimes and judicial systems, which may act as a barrier for the attraction of R\&D by MNEs. While intellectual property rights protection laws and their enforcement provide necessary protection to the fruits of R\&D (patent, copyrights, trademarks, etc.), broader institutions are complementary to R\&D investment, especially during the post-R\&D stage, and hence help realize the commercial values of R\&D (Lin et al., 2010). Therefore, both intellectual property rights protection and overall institutional quality could positively influence the $R \& D$ investment by MNEs. There is, however, counterargument to the importance of institutional quality. Zhao (2006) finds that MNEs use internal organization to substitute for weak IPR protection in countries with poor institutional environments and still benefit from conducting $R \& D$ in these countries. On balance, how institutional quality affects R\&D by MNEs is uncertain.

Finally, FDI stock of the MNE affiliates in a host country may also be a determinant of R\&D investment in the host country. FDI stock reflects the duration of MNE operations in a given country and also the significance of the host country as an investment location (Lipsey, 2000). How FDI stock impacts on R\&D investment reflects the evolving pattern over time of R\&D activities in a host country. According to the theory of gradual development, MNEs pass through four stages in their globalization: (1) indirect export using trading companies (2) direct exports by creating local sales subsidiaries), (3) local production, and (4) consolidated exports (creating sales and production centers) (Dunning, 1993). R\&D activities are functions that MNEs ultimately 
transfer to a host country during the final stags of development, when globalization has reached its high point (Mudambi \& Mudambi, 2005; UNCTAD, 2005; Motohashi, 2015). Along this line of thought, FDI stock is expected to have a positive impact on R\&D intensity. However, some authors argue that evolutionary models are inadequate to describe MNE strategies (Granstrand et al., 1993). R\&D intensive FDI may also occur as greenfield investment in which case FDI stock does not significantly influence the R\&D intensity of MNE affiliates. Therefore, the direction of the influence from FDI stock is indeterminate.

A major contribution of this study is to examine the motives and determinants of MNEs' R\&D globalization using industry-level data. The two important benefits of the industry-level analysis in this stdudy have been discussed in Section 1. While the findings from this study may corroborate or challenge existing country-and firm-level studies on drivers of R\&D globalization, these findings fill an important gap in the empirical literature on R\&D globalization and provides important comparisons with the above findings from country-level and firm-level studies. The comparison helps assess the robustness of the current theoretical and conceptual framework for R\&D globalization, thus contributing to strengthening our knowledge on this issue.

\section{Trends and Patterns of the Globalization of R\&D by U.S.-Based MNEs}

In order to set the stage for the regression analysis, this section surveys the trends and patterns of overseas R\&D investment by U.S.-based MNEs. Data used in this section is from Bureau of Economic Analysis, the Department of Commerce (BEA). This dataset contains information about U.S.-based MNEs' R\&D investment in a wide range of developed and developing countries and therefore provides an accurate gauge of the globalization of R\&D by U.S.-based MNEs. In the regression analysis discussed in Section 4, due to the need to capture the technology-seeking motive with the industry-level R\&D data, the regression sample is limited to 23 countries, of which industry-level R\&D data are available from the OECD ANBERD Database. (Note 1) Before we perform regression analysis to examine the determinants of overseas $R \& D$ investment based on the experience of these countries, it is worthwhile to present a thorough picture of global $R \& D$ investment by U.S.-based MNEs in both developed and developing countries with the data from BEA.

Annual overseas R\&D expenditure of U.S.-based MNEs more than doubled from around US\$ 18 billion in 1999 to around US\$ 42 billion in 2008. The share of overseas R\&D expenditure in total corporate R\&D expenditure increased from about $13 \%$ to $17 \%$, which suggests that globalization of R\&D by MNEs is an ongoing and deepening process. In terms of the industrial structure of R\&D investment, the share of manufacturing's R\&D expenditure in total R\&D expenditure decreased from $84 \%$ in 1999 to $76 \%$ in 2008 and the share of manufacturing's R\&D expenditure in overseas R\&D expenditure decreased from $90 \%$ in 1999 to $76 \%$ in 2008 , which suggests falling importance of the manufacturing sector in R\&D activities (Table 1). The contraction of manufacturing's share of R\&D expenditure mirrored the expansion of service's share of R\&D expenditure, as shown in Table 2. Service sectors such as "Wholesale trade", "Information" and "Professional, scientific, and technical services" became increasingly important recipients of U.S.-based MNEs' overseas R\&D expenditure. Notwithstanding this trend of shifting towards service sectors, manufacturing's share of R\&D is still dominant so far. The econometric analysis in Section 4 will be focused on the manufacturing industries due to the difficulty of making concordance between service sectors in International Standard Industrial Classification (ISIC) rev.3 used in the OECD ANBERD Database and service sectors in NAICS used in the data from BEA.

Table 3 summarizes two aspects of information. The first is the R\&D expenditure by U.S.-based MNEs in the manufacturing sector of the host country as a share of global overseas R\&D expenditure in the manufacturing sector by U.S.-based MNEs. These data show the dispersion of overseas manufacturing R\&D of U.S.-based MNEs across various countries or regions. In 2008, the total amount of U.S.-based MNEs' R\&D expenditure in China was 3\% of U.S.-based MNEs' global R\&D expenditure in manufacturing, while the corresponding share in 1999 was $2 \%$. 
Table 1. R\&D expenditure of U.S.-based MNEs during 1999-2008

\begin{tabular}{ccccccccc}
\hline & All sectors & \multicolumn{2}{c}{ Manufacturing } & \multicolumn{2}{c}{ Manufacturing share } \\
\hline & Total & \multicolumn{2}{c}{ Foreign affiliates } & Total & Foreign affiliates & \multicolumn{2}{c}{ Total } & Foreign affiliates \\
\cline { 2 - 9 } & $\$$ bn & \$ bn & \% of total & \$ bn & \$ bn & $\%$ of total & $\%$ & $\%$ \\
\hline 1999 & 144 & 18 & 13 & 121 & 16 & 13 & 84 & 90 \\
2000 & 156 & 20 & 13 & 128 & 18 & 14 & 82 & 90 \\
2001 & 163 & 20 & 12 & 133 & 17 & 13 & 81 & 88 \\
2002 & 158 & 21 & 13 & 129 & 19 & 15 & 81 & 89 \\
2003 & 163 & 23 & 14 & 133 & 20 & 15 & 81 & 87 \\
2004 & 190 & 26 & 14 & 152 & 22 & 15 & 80 & 87 \\
2005 & 205 & 28 & 13 & 167 & 24 & 14 & 81 & 85 \\
2006 & 214 & 30 & 14 & 171 & 24 & 14 & 80 & 82 \\
2007 & 238 & 34 & 14 & 187 & 28 & 15 & 79 & 81 \\
2008 & 240 & 42 & 17 & 182 & 32 & 17 & 76 & 76 \\
\hline
\end{tabular}

Source: author's own calculation based on data from Bureau of Economic Analysis, the Department of Commerce.

Table 2. Industrial distribution of overseas R\&D expenditure, 1999-2008

\begin{tabular}{lcc}
\hline & \multicolumn{2}{c}{ All countries (\% of total) } \\
\cline { 2 - 3 } & $1999-2001$ & $2006-2008$ \\
\hline All industries & 100 & 100 \\
Mining & 0.05 & 0.18 \\
Manufacturing & 89.33 & 79.02 \\
Food & 1.47 & 1.43 \\
Chemicals & 23.45 & 22.64 \\
Primary and fabricated metals & 0.74 & 0.97 \\
Machinery & 3.95 & 3.33 \\
Computers and electronic products & 24.78 & 16.49 \\
Electrical equipment, appliances, and components & 1.44 & 1.55 \\
Transportation equipment & 28.55 & 26.68 \\
Wholesale trade & 3.29 & 4.33 \\
Information & 1.65 & 4.23 \\
Finance (except depository institutions) and insurance & 0.01 & 0.01 \\
Professional, scientific, and technical services & 4.34 & 11.88 \\
\hline
\end{tabular}

Source: Author's own calculation based on data from Bureau of Economic Analysis, the Department of Commerce.

Table 3. R\&D share (\%) and R\&D intensity (\%)

\begin{tabular}{|c|c|c|c|c|}
\hline \multirow[t]{2}{*}{ Country } & \multicolumn{2}{|c|}{$\begin{array}{l}\text { R\&D expenditure by U.S.-based MNEs in the } \\
\text { manufacturing sector of the host country as a } \\
\text { share of global overseas R\&D expenditure in the } \\
\text { manufacturing sector by U.S.-based MNEs (\%) }\end{array}$} & \multicolumn{2}{|c|}{$\begin{array}{l}\text { R\&D intensity (R\&D expenditure as a share of } \\
\text { value-added) by U.S.-based MNEs in the } \\
\text { manufacturing sector of a host country (\%) }\end{array}$} \\
\hline & 1999 & 2008 & 1999 & 2008 \\
\hline All Countries Total & 1 & 1 & 5.2 & 6.1 \\
\hline Canada & 9.8 & 6.3 & 3.9 & 3.9 \\
\hline Europe & 67.5 & 67.1 & 5.6 & 6.8 \\
\hline Austria & 0.5 & 1.0 & 4.4 & 9.9 \\
\hline Belgium & 1.5 & 2.8 & 2.6 & 6.8 \\
\hline Czech Republic & 0.0 & 0.3 & 0.6 & 2.2 \\
\hline Denmark & 0.3 & .. & 5.5 & .. \\
\hline Finland & 0.4 & 0.6 & 7.5 & 11.6 \\
\hline France & 8.6 & 6.6 & 6.3 & 6.8 \\
\hline Germany & 20.4 & 22.7 & 7.3 & 11.6 \\
\hline Greece & 0.0 & 0.1 & 1.2 & 1.2 \\
\hline Hungary & 0.1 & .. & 1.6 & .. \\
\hline Ireland & 1.5 & 2.7 & 1.9 & 2.9 \\
\hline Italy & 2.9 & 1.6 & 2.7 & 2.6 \\
\hline Netherlands & 2.1 & 4.0 & 3.2 & 6.3 \\
\hline
\end{tabular}




\begin{tabular}{|c|c|c|c|c|}
\hline Norway & .. & 0.1 & .. & 1.3 \\
\hline Poland & 0.2 & 0.1 & 3.4 & 0.6 \\
\hline Portugal & 0.1 & 0.1 & 1.3 & 3.5 \\
\hline Russia & 0.0 & 0.1 & -3.0 & 0.6 \\
\hline Spain &.. & 1.7 &.. & 4.9 \\
\hline Sweden & 6.3 & 4.7 & 35.8 & 32.3 \\
\hline Switzerland &.. & 2.3 & .. & 6.4 \\
\hline Turkey & 0.0 & 0.2 & 0.5 & 0.9 \\
\hline United Kingdom & 19.8 & 14.1 & 6.1 & 7.1 \\
\hline Latin America & 3.2 & 4.3 & 1.6 & 2.1 \\
\hline Argentina & 0.1 & 0.2 & 0.5 & 0.8 \\
\hline Brazil & 1.7 & 2.4 & 2.6 & 2.8 \\
\hline Chile & 0.0 & .. & 0.2 &.. \\
\hline Colombia & .. & 0.0 &.. & 0.9 \\
\hline Mexico & 1.1 &.. & 1.3 &.. \\
\hline Africa & 0.1 & 0.1 & 1.2 & 1.3 \\
\hline Egypt & 0.0 & 0.0 & 2.1 & 1.1 \\
\hline South Africa & 0.1 & 0.1 & 1.6 & 2.1 \\
\hline Israel & 1.1 & 3.4 & 18.7 & 36.8 \\
\hline Asia and Pacific & 18.3 & 18.8 & 7.0 & 6.9 \\
\hline Australia & 1.7 & 2.6 & 3.4 & 5.7 \\
\hline China & 1.9 & 3.3 & 9.6 & 6.5 \\
\hline Hong Kong &.. & 0.2 &.. & 2.9 \\
\hline India & 0.1 & 1.4 & 2.3 & 12.9 \\
\hline Indonesia & 0.0 & 0.0 & 0.4 & 0.4 \\
\hline Japan & 8.3 & 5.0 & 10.8 & 12.7 \\
\hline Korea, Republic of & 0.6 & 3.0 & 6.4 & 14.6 \\
\hline Malaysia & 1.0 & 1.2 & 5.4 & 9.0 \\
\hline New Zealand & 0.0 & 0.1 & 1.0 & 3.3 \\
\hline Philippines & 0.2 & .. & 1.9 & .. \\
\hline Singapore & .. & 1.6 &.. & 4.4 \\
\hline Taiwan & 0.7 & .. & 7.2 &.. \\
\hline Thailand & 0.0 & 0.2 & 0.4 & 1.2 \\
\hline
\end{tabular}

Note. (1) Source: Author's own calculation based on data from Bureau of Economic Analysis, Department of Commerce. (2) “.." means data are unavailable.

Europe as a whole absorbed more than $67 \%$ of the overseas R\&D investment by U.S.-based MNEs in 1999 and maintained this proportion in 2008. Germany and the U.K. were the two countries where R\&D investment by U.S.-based MNEs was most concentrated. The Republic of Korea's share increased from $0.6 \%$ to $3 \%$ of the world total, while Japan's share fell from $8 \%$ to 5\%. Both China and India have become more important as destinations of R\&D investment from the U.S. in terms of the absolute scale, which is consistent with the findings in Moncada-Paternò-Castello, Vivarelli and Voigt (2011).

While share of R\&D in a host country in total overseas R\&D expenditure by U.S.-based MNEs informs us of one aspect of the global position of a host country, $R \& D$ intensity ( $R \& D$ expenditure as a share of value-added) in manufacturing is an indicator of how technology intensive or R\&D intensive the U.S-based MNEs in the host country are. The third and fourth columns of Table 3 present the R\&D intensity (R\&D expenditure as a share of value-added) of U.S.-based MNEs in the manufacturing industry of a country or region. The world average R\&D intensity in manufacturing by U.S.-based MNEs increased from 5\% in 1999 to 6\% in 2008. R\&D intensity by U.S.-based MNEs in Europe also grew from 6\% to 7\%. U.S.-based MNEs increased their R\&D intensity in both the manufacturing sectors of the Republic of Korea and Japan, with the extent of growth of R\&D intensity being larger in the former. Interestingly, unlike the absolute amount of R\&D, R\&D intensity of U.S.-based MNEs in India and that in China had different trends. India enjoyed an increase in R\&D intensity of U.S-based MNEs from $2.3 \%$ in 1999 to $12.9 \%$ in 2008. China, in contrast, experienced a decrease in R\&D intensity of U.S. -based MNEs from $9.6 \%$ in 1999 to $6.5 \%$ in 2008, which suggests that R\&D investment may have not been able to keep pace with the output expansion of U.S.-based MNEs in China. R\&D intensity is better than R\&D shares as an indicator of the technology intensity of MNEs' operation. Therefore, in the regression analysis in Section 4, R\&D intensity of U.S-based MNEs in the host country industry is adopted as the dependent variable of interest.

Apart from inter-country differences in R\&D intensity, there are significant inter-industry differences in $R \& D$ 
intensity (Table 4). The world average values of R\&D intensity of "Food" and "Metals" are lowest and those of "Computers" and "Transports" are highest. These inter-industry differences in R\&D intensity imply that industry-level data will be more suitable for examining the globalization of R\&D of U.S-based MNEs than country-level data.

Table 4. $R \& D$ intensity ( $R \& D$ expenditure as a share of value-added) by U.S.-based MNEs in various manufacturing industries and countries (\%)

\begin{tabular}{|c|c|c|c|c|c|c|c|c|}
\hline \multirow{2}{*}{ Country } & \multicolumn{2}{|c|}{ Food } & \multicolumn{2}{|c|}{ Chemicals } & \multicolumn{2}{|c|}{ Primary and fabricated metals } & \multicolumn{2}{|c|}{ Machinery } \\
\hline & 1999 & 2008 & 1999 & 2008 & 1999 & 2008 & 1999 & 2008 \\
\hline All Countries Total & 2.0 & 1.7 & 7.4 & 8.1 & 1.2 & 1.6 & 4.0 & 3.9 \\
\hline Canada & 1.0 & 0.9 & 9.2 & 9.0 & 0.5 & 0.9 & 1.3 & 1.3 \\
\hline Europe & 2.3 & 2.4 & 8.2 & 9.6 & 1.6 & 2.1 & 4.1 & 4.4 \\
\hline Austria & 1.3 & 0.9 & 4.2 & 9.9 & 1.9 & 0.0 & 1.6 & 14.1 \\
\hline Belgium & 0.7 & 0.4 & 5.4 & 20.5 & .. & 1.6 & 1.9 & 2.7 \\
\hline Czech Republic & .. & .. & 2.9 & 4.3 & 0.0 & 1.3 & 0.0 & 0.9 \\
\hline Denmark & 3.0 & 0.0 & .. & 4.9 & 2.8 & 2.3 & .. & .. \\
\hline Finland & 0.0 & 5.9 & 1.7 & 20.3 & 6.1 & 2.2 & 0.0 & .. \\
\hline France & 3.3 & 2.7 & 12.3 & 7.2 & 1.8 & 2.3 & 4.4 & 3.8 \\
\hline Germany & 1.3 & 7.1 & 6.5 & 12.7 & 1.7 & 1.7 & 5.3 & 6.1 \\
\hline Greece & 1.8 & 0.0 & 1.6 & 6.1 & 0.0 & 9.1 &.. & 0.0 \\
\hline Hungary &.. & 0.9 & 6.3 & 3.1 &.. & 1.8 & 0.0 & 0.3 \\
\hline Ireland & .. & 1.7 & 1.6 & 2.7 & .. & 0.0 & .. & 0.0 \\
\hline Italy & 0.7 & 1.4 & 7.8 & 8.0 & 0.7 & 2.4 & 4.3 & 2.3 \\
\hline Netherlands & 1.5 & 3.7 & 4.5 & 15.5 & 1.6 & 0.4 & 0.6 & 4.2 \\
\hline Norway & .. & 0.0 & 6.0 & 4.4 & 0.0 & .. & 3.4 & 0.9 \\
\hline Poland & 2.7 & 1.6 & 1.0 & 1.3 & 0.0 & .. & 0.0 & 1.7 \\
\hline Portugal & 0.7 &.. & 1.4 & 9.6 & 0.0 & 0.0 & .. & 1.5 \\
\hline Russia & 0.0 & 1.0 & -1.1 & 0.7 & 0.0 &.. & 0.0 & .. \\
\hline Spain & 0.8 & 0.4 & .. & 5.5 & 0.4 & 1.8 & 1.3 & 0.6 \\
\hline Sweden &.. & 0.6 & .. & 5.2 & 3.2 & 2.4 & 8.0 & 2.6 \\
\hline Switzerland & .. & 0.0 & 2.1 & 5.7 & 0.0 & 4.1 & 9.8 & 7.9 \\
\hline Turkey & 3.8 & .. & 1.3 & 4.1 & 0.0 & 15.4 & .. & 0.0 \\
\hline United Kingdom & 4.1 & 2.1 & 15.2 & 21.9 & 2.5 & 4.2 & 3.9 & 3.9 \\
\hline Latin America & 0.8 & 0.4 & 1.5 & 2.5 & 0.2 & 0.5 & 1.3 & 1.2 \\
\hline Argentina & 0.4 & 0.1 & 1.7 & 1.8 & 0.0 & 0.0 & .. & 0.0 \\
\hline Brazil & 1.2 & 0.2 & 1.5 & 2.7 & 0.3 & 0.5 & 1.6 & 1.8 \\
\hline Chile & .. & .. & .. & .. & .. & 0.0 & 0.0 & 0.0 \\
\hline Colombia & 1.2 & 1.0 & .. & 0.7 & 0.0 & 0.0 & .. &.. \\
\hline Mexico & 0.7 & 1.1 & 0.7 & 2.3 & .. & 0.4 & 1.0 & 0.4 \\
\hline Africa & 1.0 & 0.4 & 2.6 & 2.0 & .. & 0.0 & 2.8 & 0.4 \\
\hline Egypt & .. & .. & 1.9 & 0.7 & .. & .. & 1.4 & .. \\
\hline South Africa & .. & 0.8 & 3.2 & 3.5 & 0.0 & 0.0 & 4.5 & .. \\
\hline Israel & 0.0 & .. & 3.8 & .. & 0.0 & 0.0 & 10.5 & .. \\
\hline Asia and Pacific & 3.3 & 2.5 & 8.6 & .. & 1.2 & 1.1 & 8.2 & .. \\
\hline Australia & 2.6 & 3.2 & 6.1 & 9.5 & 1.3 & .. & 0.8 & 1.0 \\
\hline China & 0.0 & 0.4 & 3.5 & .. & .. & .. & 0.0 & 1.5 \\
\hline Hong Kong & 0.0 & .. & 1.6 & 4.7 & .. & .. & 1.1 & 0.0 \\
\hline India & .. & .. & 1.8 & 6.7 & 0.0 & 0.0 & 2.2 & .. \\
\hline Indonesia & 0.0 & .. & .. & 2.0 & 0.0 & 0.0 & 0.0 & 0.0 \\
\hline Japan & 18.6 & 3.9 & 16.1 & 18.2 & 3.8 & 3.3 & 21.9 & 6.9 \\
\hline Korea, Republic of & 1.4 & 2.6 & 0.7 & 7.2 & 0.0 & 1.1 & 5.3 & 4.4 \\
\hline Malaysia & 0.0 & 1.8 & 0.7 & 0.8 & 0.0 & 0.0 & 0.0 & .. \\
\hline New Zealand & .. & .. & .. & 2.4 & 0.0 & 0.0 & 0.0 & 7.1 \\
\hline Philippines & 3.4 & 1.9 & 2.1 & .. & 0.0 & 0.0 & 4.1 &.. \\
\hline Singapore & 0.0 & .. & 0.5 & 0.8 & .. & 0.0 & 0.8 & 0.1 \\
\hline Taiwan & .. & .. & 1.4 & .. & .. & 2.9 & 8.7 & 0.8 \\
\hline Thailand & 3.8 & 3.9 & 0.5 & 1.2 & 0.0 & .. & 2.4 & 2.6 \\
\hline
\end{tabular}

Note. (1) Source: Author's own calculation based on data from Bureau of Economic Analysis. (2) “..” means data are unavailable. 
Table 4 continued. R\&D intensity (R\&D expenditure as a share of value-added) by U.S.-based MNEs in various manufacturing industries and countries $(\%)$

\begin{tabular}{|c|c|c|c|c|c|c|}
\hline \multirow{2}{*}{ Country } & \multicolumn{2}{|c|}{ Computers and electronic products } & \multicolumn{2}{|c|}{ Electrical equipment, appliances, and components } & \multicolumn{2}{|c|}{ Transportation Equipment } \\
\hline & 1999 & 2008 & 1999 & 2008 & 1999 & 2008 \\
\hline All Countries Total & 10.0 & 15.0 & 2.9 & 4.7 & 11.6 & 16.3 \\
\hline Canada & 4.7 & 23.3 & 2.0 & 2.8 & 7.3 & 7.0 \\
\hline Europe & 9.2 & 14.7 & 3.4 & 4.5 & 16.3 & 22.5 \\
\hline Austria & 1.7 & 5.2 & 9.4 & .. & 0.4 & .. \\
\hline Belgium & 0.0 & .. & 3.2 & 6.8 & 2.9 & 1.0 \\
\hline Czech Republic & 0.0 & 2.0 & 0.0 & 0.0 & 2.0 & 5.2 \\
\hline Denmark & .. & 54.7 & .. & .. & 0.0 & 0.0 \\
\hline Finland & .. & .. & 0.0 & 10.3 & 5.1 & 0.0 \\
\hline France & 13.1 & 26.3 & 1.6 & 4.1 & 8.6 & 16.5 \\
\hline Germany & 7.2 & 21.1 & 5.6 & 7.7 & 20.9 & 34.5 \\
\hline Greece & .. & .. & .. & .. & .. & .. \\
\hline Hungary & .. & .. & .. & .. &.. & 0.2 \\
\hline Ireland & 4.4 & 6.7 & .. & 0.0 & 1.0 & 3.1 \\
\hline Italy & 6.3 & 5.9 & 2.3 & 0.8 & 6.2 & 7.1 \\
\hline Netherlands & 12.0 & 3.3 & .. & .. &.. &.. \\
\hline Norway & .. & .. & 0.0 & 0.0 & 0.0 & 0.0 \\
\hline Poland & 0.0 & 0.4 & .. & .. &.. & 1.5 \\
\hline Portugal &.. & 0.0 & 0.0 & 0.0 & 3.5 & 1.2 \\
\hline Russia & 0.0 & .. & 0.0 & 0.0 & 0.0 & 0.6 \\
\hline Spain & .. & .. & .. & 2.9 & 2.9 & 2.1 \\
\hline Sweden & .. & 77.6 & .. & .. &.. &.. \\
\hline Switzerland & 1.8 & 18.1 & .. & 2.4 &.. &.. \\
\hline Turkey & 0.0 & .. & 0.0 & 0.0 & 2.3 &.. \\
\hline United Kingdom & 16.6 & 14.8 & 1.1 & 4.8 & 16.8 & 25.7 \\
\hline Latin America & 13.6 & 8.1 & .. & .. & 2.7 & 5.1 \\
\hline Argentina & 0.0 & .. & 0.0 & 0.0 & 0.3 & 3.0 \\
\hline Brazil & .. & .. & .. & .. & 4.5 & 7.3 \\
\hline Chile & .. & .. & 0.0 &.. & 0.0 & 0.0 \\
\hline Colombia & .. & 0.0 & 0.0 & 0.0 & .. & .. \\
\hline Mexico & .. & 0.7 & .. & .. & 2.1 & 3.4 \\
\hline Africa & 0.0 & .. & 0.0 & 0.0 &.. & 4.5 \\
\hline Egypt & .. & 0.0 & 0.0 & 0.0 & 0.0 &.. \\
\hline South Africa & 0.0 & .. & 0.0 & 0.0 &.. &.. \\
\hline Israel & 21.5 & 66.4 & 0.0 & 0.0 & 0.0 &.. \\
\hline Asia and Pacific & 11.0 & 12.1 & .. &.. & 6.6 &.. \\
\hline Australia & .. & 2.6 & 0.0 & .. & .. &.. \\
\hline China & .. & 18.9 & .. & 7.0 &.. & 5.6 \\
\hline Hong Kong & .. & 2.2 & 5.5 & -7.9 &.. & 0.0 \\
\hline India & 12.5 & .. & 0.0 & 1.4 & 5.5 & 14.9 \\
\hline Indonesia & 0.0 & 0.0 & .. & .. & .. & .. \\
\hline Japan & 12.0 & 13.3 & 7.5 & .. & 5.8 & 15.0 \\
\hline Korea, Republic of & .. & 11.8 & .. & .. &.. & .. \\
\hline Malaysia & 6.5 & 11.8 & .. & .. &.. & 0.0 \\
\hline New Zealand & 0.0 & .. & 0.0 & 19.4 & 0.0 & 0.0 \\
\hline Philippines & 2.1 & 1.9 & .. & 1.4 &.. & .. \\
\hline Singapore & 8.9 & 10.6 & 0.0 & 0.9 & .. & 0.3 \\
\hline Taiwan & 12.0 & 6.1 & 0.0 & 5.7 & .. & .. \\
\hline Thailand & 0.0 & 1.3 & 0.0 & 0.0 & -11.1 & 5.7 \\
\hline
\end{tabular}

Note. (1) Source: Author's own calculation based on data from Bureau of Economic Analysis. (2) “..” means data are unavailable. 


\section{Model Specification, Data and Econometric Method}

From the discussion in Section 3, we have seen considerable inter-country and inter-industry differences in the R\&D intensity of U.S.-based MNEs. In this section, the factors that contribute to the inter-country and inter-industry pattern of R\&D intensity are formally tested. In this section, model specification will be presented. The reasons for the inclusion of the independent variables will be briefly explained, echoing the theoretical discussions in Section 2. Details on data and the econometric method will then follow.

The estimation equation is specified as follows:

$$
\begin{gathered}
\text { MNER\&Dintensity }{ }_{i j, t}-\text { MNER\&Dintensity } \\
i j, t-1 \\
\text { local_R\&Dintensity }_{i j, t}+a_{4} * a_{1}+\left(a_{2}-1\right) * \text { salesratio }_{i j, t}+a_{5} * \text { researchers }_{j, t}+a_{6} * \text { distance }_{j}+a_{7} * \\
\text { investmentposition }_{i j, t}+a_{8} * \text { insquality }_{j, t}+a_{9} * \text { year }_{t}+a_{10} * d_{i}+e_{i j, t}
\end{gathered}
$$

Or equivalently,

$$
\begin{aligned}
& M N E R \& \text { Dintensity } y_{i j, t}=a_{1}+a_{2} * M N E R \& \text { Dintensity }_{i j, t-1}+a_{3} * \text { local_R\&Dintensity }_{i j, t}+a_{4} * \\
& \text { salesratio }_{i j, t}+a_{5} * \text { researchers }_{j, t}+a_{6} * \text { distance }_{j}+a_{7} * \text { investmentposition }_{i j, t}+ \\
& a_{8} * \text { insquality }_{j, t}+a_{9} * \text { year }_{t}+a_{10} * i d_{i}+e_{i j, t} \\
& e_{i j, t}=u_{i j}+\varepsilon_{i j, t}
\end{aligned}
$$

where $i$ is the industry index, $j$ is the country index, $t$ is the time index.

The error term $e_{i j, t}$ consists of a country-industry fixed effect $u_{i j}$ and an observation specific error $\varepsilon_{i j, t}$.

The independent variable MNER\&Dintensity is the R\&D intensity of the affiliates of U.S.-based MNEs. Empirically, two measures could be used to proxy for the R\&D intensity variable. One is the share of $R \& D$ expenditure in value-added, and the other is the share of R\&D expenditure in total sales. Value added is a preferable measure of production because it indicates the extent to which a firm's sales result from its own production rather than from production that originates elsewhere, whereas total sales do not distinguish between these two sources of production (Mataloni, 1995). Therefore, the regression results using the share of R\&D expenditure in value-added as the independent variable are regarded as the main empirical results (Tables 8 and 9), while the regression results with the share of $R \& D$ expenditure in total sales as the independent variable provide robustness checks (Tables 10 and 11). Industry dummy $i d_{i}$ and year dummy year $_{t}$ reflect how differences in global average R\&D intensity of various industries and years influence the R\&D intensity of U.S.-based MNEs. The inclusion of these two dummies is necessary because average R\&D intensity differ across industries and time (Note 2).

Based on the technology-seeking hypothesis, the domestic technological capability of the relevant industry in the host country is an important consideration in MNEs' R\&D location decision and is measured by R\&D expenditure as a percentage of output (value added) in a given industry in a host country, i.e. local_R\&Dintensity. If R\&D investment of MNEs is partly driven by the technology-seeking motive, then a higher local_R\&Dintensity implies a higher MNER\&Dintensity, which is the R\&D intensity of U.S.-based MNEs in industry $i$ of a host country $j$ in year $t$. When the technology-seeking motive exists, the coefficient of local_R\&Dintensity is expected to be positive.

A major difference between this study and previous country-level studies is that industry-level R\&D intensity of host countries instead of the country-level R\&D intensity of host countries is adopted to capture the technology-seeking motive of U.S.-based MNEs. In this study, the R\&D intensity measure of an industry in a host country is the share of industry R\&D expenditure in the industry value-added.

Two variables are included to capture the importance of adapting products and production processes to suit domestic market conditions in determining inter-country and inter-industry variation in R\&D intensity, or the technology-adaptation motive. They are the geographic distance between the U.S. and a given host country distance, and the domestic market orientation of U.S.-based MNE affiliates measured by the sales as a percentage of global sales salesratio. (Note 3) The share of sales in industry $i$ of country $j$ in global sales in industry $i$ is used to measure the relative market size of industry $i$ of country $j$.

As discussed in Section 2, longer distance to the home country (distance) can either increase or decrease $R \& D$ intensity of foreign affiliates. The impact of domestic market orientation on local R\&D effort can go either way as well. Therefore, the signs of the coefficients for these two variables are uncertain. Two variables are used to capture the conduciveness of the economic environment for R\&D activities. They are researchers in R\&D per 
thousand population (researchers) and institutional quality (insquality). The aggregate FDI stock of U.S.-based MNE affiliates in each industry of each host country (investmentposition) is employed to capture the effect from the extant FDI stock on the R\&D investment by MNEs. The explanatory variables are listed in Table 5 with the expected signs of the coefficient of each variable given in brackets.

Table 5. List of variables in the regression and their respective expected signs

\begin{tabular}{|c|c|}
\hline MNER\&Dintensity ${ }_{i j, t}$ & $\begin{array}{l}\text { the ratio of investment in research and development to the value-added by affiliates of U.S.-based MNEs in } \\
\text { industry } i \text { of country } j \text { in year } t \\
\text { (two measures: R\&D expenditure as a share of total sales; R\&D expenditure as a s share of value-added) }\end{array}$ \\
\hline local_R\&Dintensity $_{i j, t}(+)$ & $\begin{array}{l}\text { the ratio of investment in research and development to the value-added by business enterprises in industry } \\
\qquad i \text { of country } j \text { in year } t\end{array}$ \\
\hline salesratio $_{i j, t}(+)$ & the ratio of sales in industry $i$ of country $j$ to the total sales in industry $i$ of the world. \\
\hline distance $_{j}(-$ or +$)$ & great-circle distance between the capital city of the given country $i$ to Washington DC \\
\hline investmentposition $_{i j, t}(-$ or +$)$ & $\begin{array}{l}\text { the U.S. direct investment position abroad on a historical-cost basis in industry } i \text { of country } j \text { in year } t \\
\text { (dollars) }\end{array}$ \\
\hline insquality $_{j, t}(+)$ & $\begin{array}{l}\text { two measures: legal structure and property rights of county } j \text { in year } t \\
\text { overall insitutional quality of county } j \text { in year } t\end{array}$ \\
\hline researchers $_{j, t}(+)$ & number of researchers in $R \& D$ per thousand population \\
\hline
\end{tabular}

Data compilation is composed of three parts. Firstly, I obtain respectively from the OECD ANBERD Database and the STAN Database for Structural Analysis the R\&D expenditure and the value added in seven manufacturing industries. The business enterprise $R \& D$ expenditure is then divided by the value-added variable, which gives us the R\&D intensity of each industry in each country. Secondly, the chain-linked summary index of institutional quality published in the Economic Freedom of the World database is used to proxy for the overall insitutional quality of an economy. (Note 4) This overall index measures institutional quality in terms of five criteria: (1) size of government, (2) legal structure and property rights, (3) access to sound money, (4) freedom to trade internationally, and (5) regulation of credit, labour and business. It ranges from zero to ten, with higher values indicating stronger institutional quality. The chain-linked sub-indicator for the second area "legal structure and property rights" is also used as a measure of institutional quality in the regression analysis. This is because property rights protection itself has received much attention in the literature about FDI and the literature about firm R\&D activities. The sub-indicator is also on a scale of zero to ten.

Thirdly, the number of researchers in R\&D per thousand population is obtained from the World Development Indicators. Fourthly, distance is measured as the great-circle distance between the capital city of the given country to Washington DC. Lastly, the previous four variables are merged with the direct investment abroad data of majority-owned nonbank foreign affiliates from the U.S. reported by BEA. The dependent variable $\left(\right.$ MNER\&Dintensity $\left._{i j, t}\right)$ and the two explanatory variables (salesratio ${ }_{i j, t}$, investmentposition $\left.{ }_{i j, t}\right)$ are from this database.

Twenty-three countries and seven manufacturing industries are covered in the final sample, which is a compilation of six data sources. The seven industries are "Food", "Chemicals", "Metals", "Machinery", "Computers", "Electrics" and "Transports". Bureau of Economic Analysis follows North American Industry Classification System (NAICS) when reporting the data on direct investment abroad for majority-owned nonbank foreign affiliates. In order to use the R\&D information in the OECD ANBERD database, which follows the International Standard Industrial Classification rev. 3 (ISIC rev.3), I correspond NAIC with ISIC rev.3, which requires some industries under ISIC rev. 3 to be grouped into the seven industries used in the final sample.

The time period of this study is from 2000 to 2008. This time period is chosen because BEA compiled consistent data on direct investment abroad by U.S. multinational enterprises based on NAICS for this period. According to the BEA website, there is a discontinuity in the time series at 1999 where the industry classifications are changed from Standard Industrial Classification (SIC) to the North American Industry Classification System (NAICS). Besides this problem, the institutional quality measures used in this study are only available for each year from the year 2000 onwards. These two conditions lead to the choice of the years 2000-2008 as the time period.

The inclusion of the lagged dependent variable on the right hand side of Eq. 2 creates a dynamic structure. Under this structure, the error term, which includes country-industry fixed effects, may co-vary with the lagged dependent variable. Hence, an Ordinary Least Square (OLS) estimator will be inconsistent. A fixed-effect estimator is also biased since within transformation will make the transformed error and lagged dependent 
variable correlated. Also, the two variables salesratio and investmentposition may be endogenous. (Note 5) Therefore, instrumental variables are required to deal with this problem as well as the endogeneity of other explanatory variables.

A consistent estimator under these circumstances is the system GMM estimator (Blundell \& Bond, 1998). Holtz-Eakin, Newey, and Rosen (1988) and Arellano and Bond (1991) first proposed the difference GMM estimator. Later, Blundell and Bond (1998) augment Arellano-Bond (1991) with an additional assumption that first differences of instrumenting variables are uncorrelated with the fixed effects, which then allows the introduction of more instruments and can dramatically improve efficiency. The "system GMM estimator" that combines the variables in differences and levels also has better asymptotic properties. By using internal instruments (lagged variables and differenced variables), the dynamic panel estimation applied in the analysis allows for the likely weak endogeneity of the main regressors.

I apply the two-step system GMM estimator, which is asymptotically more efficient than the one-step estimator in the presence of heteroskedasticity of the error terms (Roodman, 2006). Also, to avoid downward bias of the two-step standard error, the robust standard errors proposed by Windmeijer (2005) are adopted. Whether the GMM estimator is consistent or not crucially depends on the validity of the instruments. To ensure this is the case in the specification, I conduct three specification tests: tests of over-identifying restrictions based on Hansen $\mathrm{J}$ Test and Sargan Test, and the Arellano-Bond test for second-order serial correlation in the error term (Wooldridge, 2002; Roodman, 2006). The autocorrelation test and the robust estimates of the coefficient standard errors assume no correlation across individuals in the idiosyncratic disturbances. Time dummies and industry dummies make this assumption more likely to hold since the correlation due to the common time trend and industry trend is captured. Therefore, time dummies and industry dummies are included in the specification.

\section{Results}

Summary statistics of the variables used in the regression analysis are shown in Table 6. The OLS estimation result using overall institutional quality measure is reported in Table 7 for comparison with the main results in Tables 8 and 9. The main regression results presented in these two tables are obtained using the sub-indicator of legal structure and property rights and the overall institutional quality measure, respectively, to reflect the effect from institutional quality on R\&D intensity. It is observed that the result of the OLS estimation is close to the results of the system GMM estimation.

Table 6. Summary statistics on variables used in the regression analysis

\begin{tabular}{ccccc}
\hline & Maximum & Minimum & Mean & Standard Deviation \\
\hline local_R\&Dintensity & 1.26 & $9.30 \mathrm{E}-05$ & 0.070 & 0.11 \\
salesratio & 0.30 & 0.00 & 0.030 & 0.043 \\
researchers & 80 & 0.22 & 2.7 & 1.6 \\
insquality & 9.6 & 3.6 & 7.2 & 1.4 \\
investmentposition & 20640 & -3298 & 1210 & 3292 \\
distance & 15936 & 743 & 7621 & 0.016 \\
MNER\&Dintensity $(R \& D$ expenditure & 0.17 & 0.00 & 0.011 & 0.073 \\
as a share of total sales) & & & & 0.044 \\
MNER\&Dintensity $(R \& D$ expenditure & 1.5 & -0.096 &
\end{tabular}

Source: Author's own calculation based on data from Bureau of Economic Analysis, the Department of Commerce.

Table 7. Ordinary least squares estimation (MNE R\&D intensity defined as a share of value-added)

\begin{tabular}{|c|c|c|c|}
\hline Regressors & Coefficient & Standard Error & P-value \\
\hline Local R\&D intensity (local_R\&Dintensity) & $0.085^{* *}$ & 0.034 & 0.012 \\
\hline Market share (salesratio) & $0.48 * * *$ & 0.11 & 0 \\
\hline Density of researchers (researchers) & $0.10 * * *$ & 0.033 & 0.0010 \\
\hline Geographic distance (distance) & $3.2 \mathrm{E}-06 * *$ & $1.5 \mathrm{E}-06$ & 0.026 \\
\hline Institutional quality (overall institutional quality measure) & -0.0031 & 4.0E-03 & 0.43 \\
\hline FDI stock (investmentposition) & $2.3 \mathrm{E}-06$ & $1.6 \mathrm{E}-06$ & 0.16 \\
\hline Number of observations & & 811 & \\
\hline
\end{tabular}

Source: Author's own calculation.

Note. $*$, ** and $* * *$ indicate $10 \%, 5 \%$ and $1 \%$ significance respectively. 
Table 8 shows that the coefficient of local_R\&Dintensity is positively signed and statistically significant at the $1 \%$ level. This result is consistent with the technology-seeking hypothesis that U.S.-based MNEs may increase R\&D intensity to absorb knowledge in the host economy. This provides evidence in support of the technology-seeking motive behind the R\&D investment of MNEs. The coefficient of local_R\&Dintensity is 0.073 , which means that, ceteris paribus, a $1 \%$ increase in the R\&D intensity of the industry in the host country is, on average, associated with a $0.073 \%$ increase in the R\&D intensity of U.S.-based MNEs in the industry of this country. Note that a $0.073 \%$ increase is not small relative to the mean R\&D intensity of U.S.-based MNEs, which is equal to $1.1 \%$ (Table 8 ).

To examine the technology-adaptation motive, we need to look at the variable salesratio, which proxies for market size, and the variable distance, which measures geographical distance. The coefficient of salesratio $_{i j, t}$ is positive and significant at the $5 \%$ level. The coefficient of salesratio is 0.93 , which implies that, ceteris paribus, a $1 \%$ increase of the share of market will increase the R\&D intensity of U.S.-based MNEs by $0.93 \%$. This finding supports the hypothesis that market size is important for the return to R\&D investment and hence larger market size tends to accommodate more intensive R\&D activities. Geographic distance is not found to be significant in explaining the R\&D intensity of U.S.-based MNEs. The insignificance of geographic distance is consistent with the finding in Athukorala and Kohpaiboon (2010).

As for the role of human capital, the variable reseachers is found to exert a positive influence on the R\&D intensity of U.S.-based MNEs and is significant at the 1\% level. Ceteris paribus, for each additional researcher in a thousand people, R\&D intensity of U.S.-based MNEs increases by $1.1 \%$. This is consistent with the hypothesis that abundance of available researchers is a main driver of multinational R\&D investment. FDI stock (investmentposition) is found to be negatively associated with the R\&D intensity of U.S.-based MNES and is significant at the $10 \%$ level, which implies that R\&D investment is not a process where the production units already located in the country become more and more engaged in R\&D over time and gradually enhance the quality and scope of their $\mathrm{R} \& \mathrm{D}$. As to the institutional quality in terms of legal structure and property rights, it is found to exert a negative impact on R\&D intensity of U.S.-based MNEs and is significant at $10 \%$ level. The negative relationship holds when Mexico, the only developing country is dropped out of the sample (Note 6).

In Table 9, the overall institutional quality is adopted and the results are similar to those in Table 8. In Tables 10 and 11, the independent variable is the share of R\&D expenditure in total sales. I apply the same econometric model and the results are largely consistent. However, unlike the results in Tables 7 and 8, the institutional quality variable is not significant at the $10 \%$ level in Tables 10 and 11 . But the coefficients of host country R\&D intensity, ratio of local sales to world sales and the number of researchers are still all positively signed and significant at the $5 \%$ level.

Table 8. Determinants of R\&D intensity of U.S.-based MNEs in overseas manufacturing sectors (R\&D intensity defined as R\&D expenditure as a share of value-added)

\begin{tabular}{cccc}
\hline Regressors & Coefficient & Standard Error & P-value \\
\hline Initial R\&D intensity (MNER\&Dintensity) & $0.59^{* * *}$ & 0.10 & 0.000 \\
Local R\&D intensity (local_R\&Dintensity) & $0.073^{* *}$ & 0.037 & 0.048 \\
Market share (salesratio) & $0.93^{* * *}$ & 0.44 & 0.036 \\
Density of researchers (researchers) & $0.011^{* * *}$ & 0.0038 & 0.0040 \\
Geographic distance (distance) & $2.30 \mathrm{E}-06$ & $2.00 \mathrm{E}-06$ & 0.25 \\
Institutional quality (measure of legal protection) & $-0.015^{*}$ & $7.80 \mathrm{E}-03$ & 0.055 \\
FDI stock (investmentposition) & $-3.45 \mathrm{E}-06^{*}$ & $2.94 \mathrm{E}-07$ & 0.17 \\
AR(2) test (p-value) & & 0.54 & 0.36 \\
Hansen J test (p-value) & & 0.25 & \\
Sargan test (p-value) & & 744 & \\
Number of observations & & &
\end{tabular}

Note. (1) S.e. denotes heteroskedasticity-robust error. (2) AR (2) is a test of second-order residual serial correlation. (3) Time dummies are included to capture period specific effect but are not reported. (4) Source: Author's own calculation. 
Table 9. Determinants of R\&D intensity of U.S.-based MNEs in overseas manufacturing sectors (R\&D intensity defined as R\&D expenditure as a share of value-added)

\begin{tabular}{cccc}
\hline Regressors & Coefficient & Standard Error & P-value \\
\hline Initial R\&D intensity (MNER\&Dintensity) & $0.59^{* * * *}$ & 0.090 & 0.000 \\
Local R\&D intensity (local_R\&Dintensity) & $0.069^{* *}$ & 0.030 & 0.032 \\
Market share (salesratio) & $1.17^{* *}$ & 0.51 & 0.021 \\
Density of researchers (researchers) & $0.009^{* * *}$ & 0.0025 & 0.000 \\
Geographic distance (distance) & $3.20 \mathrm{E}-06$ & $2.01 \mathrm{E}-06$ & 0.108 \\
Institutional quality (overall institutional quality measure) & $-0.043^{* *}$ & $1.90 \mathrm{E}-02$ & 0.026 \\
FDI stock (investmentposition) & $-3.41 \mathrm{E}-06^{*}$ & $2.53 \mathrm{E}-07$ & 0.18 \\
AR(2) test (p-value) & & 0.45 & 0.70 \\
Hansen J test (p-value) & & 0.32 & \\
Sargan test (p-value) & & 744 & \\
Number of observations & &
\end{tabular}

Note. (1) S.e. denotes heteroskedasticity-robust error. (2) AR (2) is a test of second-order residual serial correlation. (3) Time dummies are included to capture period specific effect but are not reported. (4) Source: Author's own calculation.

Table 10. Determinants of R\&D intensity of U.S.-based MNEs in overseas manufacturing sectors (R\&D intensity defined as R\&D expenditure as a share of total sales)

\begin{tabular}{cccc}
\hline Regressors & Coefficient & Standard Error & P-value \\
\hline Initial R\&D intensity (MNER\&Dintensity) & $0.63^{* * *}$ & 0.080 & 0.000 \\
Local R\&D intensity (local_R\&Dintensity) & $0.011^{* *}$ & 0.0052 & 0.029 \\
Market share (salesratio) & $0.098^{* *}$ & 0.042 & 0.019 \\
Density of researchers (researchers) & $0.0012^{* * *}$ & 0.00039 & 0.003 \\
Geographic distance (distance) & $3.09 \mathrm{E}-07$ & $2.10 \mathrm{E}-07$ & 0.142 \\
Institutional quality (measure of legal protection) & -0.0013 & $8.90 \mathrm{E}-04$ & 0.148 \\
FDI stock (investmentposition) & $-0.607^{*}$ & $2.94 \mathrm{E}-07$ & 0.039 \\
AR(2) test (p-value) & & 0.85 & 0.99 \\
Hansen J test (p-value) & & 0.39 & \\
Sargan test (p-value) & & 737 & \\
Number of observations & & &
\end{tabular}

Note. (1) S.e. denotes heteroskedasticity-robust error. (2) AR (2) is a test of second-order residual serial correlation. (3) Time dummies are included to capture period specific effect but are not reported. (4) Source: Author's own calculation.

Table 11. Determinants of R\&D intensity of U.S.-based MNEs in overseas manufacturing sectors (R\&D intensity defined as $R \& D$ expenditure as a share of total sales)

\begin{tabular}{cccc}
\hline Regressors & Coefficient & Standard Error & P-value \\
\hline Initial R\&D intensity (MNER\&Dintensity) & $0.62^{* * *}$ & 0.077 & 0.000 \\
Local R\&D intensity (local_R\&Dintensity) & $0.010^{* *}$ & 0.0051 & 0.043 \\
Market share (salesratio) & $0.099^{* *}$ & 0.042 & 0.019 \\
Density of researchers (researchers) & $0.0010^{* * *}$ & 0.00033 & 0.002 \\
Geographic distance (distance) & $2.65 \mathrm{E}-07$ & $1.77 \mathrm{E}-07$ & 0.135 \\
Institutional quality (overall institutional quality) & -0.0029 & $1.80 \mathrm{E}-03$ & 0.116 \\
FDI stock (investmentposition) & $-0.593^{*}$ & $2.00-07$ & 0.048 \\
AR(2) test (p-value) & & 0.86 & \\
Hansen J test (p-value) & & 0.98 & \\
Sargan test (p-value) & & 0.41 & \\
Number of observations & & 737 & \\
\hline
\end{tabular}

Note. (1) S.e. denotes heteroskedasticity-robust error. (2) AR (2) is a test of second-order residual serial correlation. (3) Time dummies are included to capture period specific effect but are not reported. (4) Source: Author's own calculation.

The validity of the estimation results is checked as follows. I use Hansen J Test and Sargan Test of over-identification to test for the validity of the instruments. The null hypothesis is that the instruments as a group are exogenous. The results are reported for each regression and none of them rejects the null hypothesis 
that the moment conditions are valid at the $10 \%$ confidence level. This result indicates that the estimations are not subject to substantial endogeneity bias. Furthermore, the Arellano-Bond test for autocorrelation in first differences, which has a null hypothesis of no autocorrelation, is performed on the regression. The test result, as reported in Table 8, cannot reject the non-presence of second order autocorrelation in all the regression at conventional confidence levels. These three specification tests point out the validity of internal instruments and the assumption of zero autocorrelation of error term, thus testifying to the validity of the estimation results.

We have seen the results based on the empirical specification in Eq. 2 and the system GMM estimator, which considers both the lagged dependent variable and the endogeneity of the independent variables. However, if one takes a close look at the R\&D intensity of U.S.-based MNEs, it is seen that a number of industries report zero value of R\&D intensity (Table 4). To confront this issue, the random-effect Tobit estimator is performed on the following specification:

$$
\begin{gathered}
\text { MNER\&Dintensity }_{i j, t}=b_{1}+b_{2} \text { local_R\&Dintensity }_{i j, t}+b_{3} * \text { salesratio }_{i j, t}+b_{4} * \text { researchers }_{j, t}+ \\
b_{5} * \text { distance }_{j}+b_{6} * \text { investmentposition }_{i j, t}+b_{7} * \text { insquality }_{j, t}+b_{8} * \text { year }_{t}+b_{9} * \text { id }_{i}+e_{i j, t}
\end{gathered}
$$

The result of the estimation is presented in Table 12 . The coefficients of host country industry R\&D intensity, market share of host country industry and number of researchers per population in the host country are still positive and significant, which are consistent with the findings based on the system GMM estimator of Equation 3. (Note 7) However, under Tobit estimation, distance becomes positive and significant at the 5\% level and FDI stock becomes insignificant, which is different from the previous conclusions. Like the case in Tables 10 and 11, institutional quality is not significant here. Therefore, the random-effect Tobit estimation strengthens the findings about the technology-seeking and the technology-adaptation motives and about the positive impact of human capital. Yet the roles of FDI stock, geographical distance and institutional quality are less clear and robust

Table 12. Random-effect Tobit estimation

( $R \& D$ intensity defined as $R \& D$ expenditure as a share of value added)

\begin{tabular}{cccc}
\hline Regressors & Coefficient & Standard Error & P-value \\
\hline Local R\&D intensity (local_R\&Dintensity) & $0.072^{* *}$ & 0.04 & 0.075 \\
Market share (salesratio) & $0.48^{* * *}$ & 0.11 & 0.00 \\
Density of researchers (researchers) & $0.011^{* * *}$ & 0.0039 & 0.004 \\
Geographic distance (distance) & $3.46 \mathrm{E}-06^{* *}$ & $1.72 \mathrm{E}-06$ & 0.045 \\
Institutional quality (overall institutional quality) & -0.0034 & $4.60 \mathrm{E}-03$ & 0.465 \\
FDI stock (investmentposition) & $1.09 \mathrm{E}-06$ & $1.79 \mathrm{E}-03$ & 0.542 \\
Uncensored observations & & 725 & \\
Number of observations & & & \\
\hline
\end{tabular}

Source: Author's own calculation.

\section{Conclusion}

Multinational enterprises continue to expand their $R \& D$ activities outside their home countries in response to competitive pressures and an increasingly global trade and investment environment. With proper policies that facilitate diffusion of technologies and knowledge from foreign affiliates, host countries can link MNEs' R\&D activities with local innovation systems to enhance domestic innovation capabilities. For government to formulate sound policies to attract $R \& D$ by MNEs, understanding the drivers of $R \& D$ globalization is a critical step.

By focusing on the R\&D investment by U.S.-based MNEs in seven manufacturing industries of twenty-three countries, this study examines the drivers of overseas R\&D investment by U.S.-based MNEs during the period 2000-2008. The empirical findings suggest that technology-seeking motive is important since higher level of $R \& D$ intensity in the relevant industry of the host country induces higher level of R\&D intensity of MNEs. Technology-adaptation motive is significant as well since MNE subsidiaries in larger markets are found to be more $R \& D$ intensive. Access to an abundant pool of researchers enhances the R\&D intensity of MNEs. These findings point to the need for policies that strengthen domestic R\&D stock, enhance human capital endowment and support a domestic market that is open to the world in order to attract overseas R\&D investment by multinational enterprises.

The roles of institutional quality, investment position of MNEs, and geographical distance, are not found to be 
robust. While institutional quality of the host country doesn't significantly affect the R\&D intensity of U.S.-based MNEs in the sample used in this study - one that is largely composed of developed countries - it is possible that institutional quality will matter more when more developing countries are included and the variation in the institutional quality of host countries becomes greater. Alternatively, the insignificance of institutional quality may suggest that while low institutional quality expose MNEs to higher risks and therefore discourage R\&D activities, MNEs may avert the risks in low institutional environment by strengthening internal organization. The insignificant result of the investment position suggests that MNE globalization may not follow an evolutionary model from production to R\&D activities, and MNEs may engage in R\&D activities even when there are relatively few production activities in a host country. This bodes well for host countries that hope to attract R\&D by MNEs and have not yet had much existing FDI. The insignificance of geographical distance implies that both mechanisms discussed in Section 2 are at play. Longer distance intensifies the need to conduct R\&D for technology adaptation to the local market and also incurs higher cost of FDI and decreases R\&D investment by MNEs.

Besides identifying the drivers of $R \& D$ globalization as discussed above, this study contributes by filling an important gap in empirical evidence on this issue. While existing country- and firm-level studies have enriched our understanding, industry-level evidence on this issue, however, is scarce. Since knowledge spill-overs that are closely related to MNE's own knowledge base are likely to be more useful than less related knowledge, it is important to make direct observation of the technological capability of the relevant industry and country where the multinational enterprise operates. Therefore, the results in this study complement existing studies in examining whether the technology-seeking motive is a driver of $R \& D$ investment by MNEs. Overall, the findings are consistent with the existing country- and firm- level studies and thus strengthen the understanding emerged from the extant literature.

In the future, a worthwhile effort is to extend the industry-level sample to include more developing countries when data become available. Given the increasing share of developing countries as destinations of overseas R\&D investment, this extension may reveal important and novel mechanisms underlying the globalization of R\&D by MNEs.

\section{Acknowledgements}

The author is grateful to Professor Prema-chandra Athukorala, Dr Jane Golley, Dr Ligang Song, Prof. Peter Drysdale and Prof. Rodney Tyers for their valuable comments and advice.

\section{References}

Ambos, T. C., Ambos, B., \& Schlegelmilch, B. B. (2006). Learning from foreign subsidiaries: An empirical investigation of headquarters' benefit from reverse knowledge transfers. International Business Review, 15(3), 294-312. http://dx.doi.org/10.1016/j.ibusrev.2006.01.002

Arellano, M., \& Bond, S. (1991). Some tests of specification for panel data: Monte Carlo evidence and an application to employment equations. Review of Economic Studies, 58(2), 277-297. http://dx.doi.org/10.2307/2297968

Athukorala, P., \& Kohpaiboon, A. (2010). Globalization of R\&D by U.S.-based multinational enterprise. Research Policy, 39(10), 1335-1347. http://dx.doi.org/10.1016/j.respol.2010.09.004

Audretsch, D. B., \& Feldman, M. P. (1996). R\&D spillovers and the geography of innovation and production. The American Economic Review, 86(3), 630-640. http://www.jstor.org/stable/2118216

Belderbos, R., Lykogianni, E., \& Veugelers, R. (2008). Strategic R\&D location in European manufacturing industries. Journal of World Economics, 144(2), 183-206. http://www.jstor.org/stable/41220013

Blundell, R., \& Bond, S. (1998). Initial conditions and moment restrictions in dynamic panel data models. Journal of Econometrics, 87(1), 115-143. http://dx.doi.org/10.1016/S0304-4076(98)00009-8

Branstetter, L. (2001). Are knowledge spillovers international or intranational in scope? Journal of International Economics, 53(1), 53-79. http://dx.doi.org/10.1016/S0022-1996(00)00068-4

Branstetter, L., Fisman, R., \& Foley, C. F. (2006). Do stronger intellectual property rights increase international knowledge transfer? Empirical evidence from U.S. firm-level panel data. The Quarterly Journal of Economics, 121(1), 321-349. http://dx.doi.org/10.1162/qjec.2006.121.1.321

Cantwell, J., \& Mudambi, R. (2005). MNE competence-creating subsidiary mandates. Strategic Management Journal, 26(12), 1109-1128. http://dx.doi.org/10.1002/smj.497 
Cantwell, J. A., Dunning, J. H., \& Janne, O. E. M. (2004). Towards a technology-seeking explanation of U.S. direct investment in the United Kingdom. Journal of International Management, 10(1), 5-20. http://dx.doi.org/10.1016/j.intman.2003.12.002

Carlsson, B. (2006). Internationalization of innovation systems: A survey of the literature. Research Policy, 35(1), 56-67. http://dx.doi.org/10.1016/j.respol.2005.08.003

Castelli, C., \& Castellani, D. (2013). The internationalisation of R\&D: Sectoral and geographic patterns of cross-border investments. Journal of Industrial and Business Economics, 40(1), 127-143. http://dx.doi.org/10.3280/POLI2013-001006

Dosso, M., \& Vezzani, A. (2015). Top R\&D investors and international knowledge seeking: The role of emerging technologies and technological proximity. IPTS Working Papers on Corporate $R \& D$ and Innovation, No. 09/2015, Institute for Prospective Technological Studies. http://dx.doi.org/10.2791/853343

Dunning, J. H. (1993). Multinational enterprises and the global economy. Harlow: Addison-Wesley.

European Commission. (2011). The 2011 EU Industrial R\&D Investment Scoreboard. Luxembourg: Publications Office of the European Union. Retrieved from http://iri.jrc.ec.europa.eu/research/docs/2011/SB2011.pdf

European Commission. (2013). The 2013 EU Industrial R\&D investment Scoreboard. Luxembourg: Publications Office of the European Union. Retrieved from http://iri.jrc.ec.europa.eu/scoreboard13.html

European Commission. (2014). The 2014 EU Industrial R\&D investment Scoreboard. Luxembourg: Publications Office of the European Union. Retrieved from http://iri.jrc.ec.europa.eu/scoreboard14.html

European Commission. (2015). The 2015 Survey on R\&D Investment Business Trends. Luxembourg: Publications Office of the European Union. Retrieved from http://iri.jrc.ec.europa.eu/survey15.html

Feinberg, S. E., \& Gupta, A. K. (2004). Knowledge spillovers and the assignment of R\&D responsibilities to foreign subsidiaries. Strategic Management Journal, 25(8-9), 823-845. http://dx.doi.org/10.1002/smj.396

Fujita, M., \& Thisse, J. (2006). Globalization and the evolution of the supply chain: Who gains and who loses? International Economic Review, 47(3), 811-836. http://dx.doi.org/10.1111/j.1468-2354.2006.00397.x

Granstrand, O., Hikanson, L., \& Sjiilander, S. (1993). Internationalization of R\&D: A survey of some recent research. Research Policy, 22(5-6). 413-430. http://dx.doi.org/10.1016/0048-7333(93)90010-F

Griffith, R., Redding, S., \& Van Reenen, J. (2004). Mapping the two faces of R\&D: Productivity growth in a panel of OECD industries. The Review of Economics and Statistics, 86(4), 883-895. http://dx.doi.org/10.1162/0034653043125194

Guimón, J. (2009). Government strategies to attract R\&D-intensive FDI. Journal of Technology Transfer, 34(4), 364-379. http://link.springer.com/article/10.1007\%2Fs10961-008-9091-1

Guimón, J. (2015). National Policies to Attract R\&D intensive FDI in Developing Countries. The Innovation Policy Platform Policy Brief. Retrieved from https://innovationpolicyplatform.org/sites/default/files/rdf_imported_documents/NationalPoliciesToAttract R\&DIntensiveFDIInDevelopingCountries.pdf

Guimón, J., \& Filippov, S. (2012). Competing for high-quality FDI: Management challenges for investment promotion agencies. Institutions and Economies, 4(2), 25-44. Retrieved from http://ijie.um.edu.my/filebank/published_article/3941/Fulltext2.pdf

Haakonsson, S. J., \& Ujjual, V. (2015). Internationalisation of R\&D: New insights into multinational enterprises' $\mathrm{R} \& \mathrm{D}$ strategies in emerging markets. Management Revue, 26(2), 101-123. http://dx.doi.org/10.1688/mrev-2015-02-Haakonsson

Hansen, M. T., \& Lovas, B. (2004). How do multinational companies leverage technological competencies? Moving from single to interdependent explanations. Strategic Management Journal, 25, 801-822. http://dx.doi.org/10.1002/smj.413

Hanson, G. H., Mataloni, R. J., \& Slaughter, M. J. (2005). Vertical production networks in multinational firms. The Review of Economics and Statistics, 87(4), 664-678. http://dx.doi.org/10.1162/003465305775098080

Hedge, D., \& Hicks, D. (2008). The maturation of global corporate R\&D: Evidence from the activity of U.S. foreign subsidiaries. Research Policy, 37(3), 390-406. http://dx.doi.org/10.1016/j.respol.2007.12.004

Helpman, E. (2006). Trade, FDI and the organization of firms. Journal of Economic Literature, 44(3), 589-630. Retrieved from http://www.aeaweb.org/articles.php?doi=10.1257/jel.44.3.589 
Holtz-Eakin, D., Newey, W., \& Rosen, H. S. (1988). Estimating vector autoregressions with panel data. Econometrica, 56(6), 1371-1395. http://dx.doi.org/10.2307/1913103

Hummels, D., Ishii, J., \& Yi, K. (2001). The nature and growth of vertical specialization in world trade. Journal of International Economics, 54(1), 75-96. Retrieved from http://www.sciencedirect.com/science/article/pii/S0022199600000933

Iammarino, S., \& McCann, P. (2013). Multinationals and economic geography: Location, technology and innovation. Cheltenham, U.K: Edward Elgar.

Iwasa, T., \& Odagiri, H. (2004). Overseas R\&D, knowledge sourcing and patenting: An empirical study of Japanese R\&D investment in the US. Research Policy, 33(5), 807-828. http://dx.doi.org/10.1016/j.respol.2004.01.002

Jaffe, A. B., Trajtenberg, M., \& Henderson, R. (1993). Geographic localization of knowledge spillovers as evidenced by patent citations. Quarterly Journal of Economics, 108(3), 577-598. Retrieved from http://www.jstor.org/stable/2118401

Kaplinsky, R. (2000). Globalisation and unequalisation: What can be learned from value chain analysis? Journal of Development Studies, 37(2), 117-146. $\quad$ Retrieved from http://www.tandfonline.com/doi/abs/10.1080/713600071

Keller, W. (2002). Geographic localization of international technology diffusion. American Economic Review, 92(1), 120-142. Retrieved from http://www.aeaweb.org/articles.php?doi=10.1257/000282802760015630

Kuemmerle, W. (1999). The drivers of foreign direct investment into research and development: An empirical investigation. Journal of International Business Studies, 30(1), 1-24. http://dx.doi.org/10.1057/palgrave.jibs.8490058

Kumar, R. (1996). Intellectual property protection, market orientation and location of overseas R\&D activities by multinational enterprises. Research Policy, 24(4), 673-688. http://dx.doi.org/10.1016/0305-750X(95)00168-C

Laurens, P., Bas, C. L., Schoen, A., Villard, L., \& Larédo, P. (2015). The rate and motives of the internationalisation of large firm R\&D (1994-2005): Towards a turning point? Research Policy, 44(3), 765-776. http://dx.doi.org/10.1016/j.respol.2014.11.001

Lewin, A. Y., Massini, S., \& Peeters, C. (2009). Why are companies offshoring innovation and quest: The emerging global race for talent. Journal of International Business Studies, 40(6), 901-925. http://dx.doi.org/10.1057/jibs.2008.92

Lin, C., Lin, P., \& Song, F. (2010). Property rights protection and corporate R\&D: Evidence from China. Journal of Development Economics, 93(1), 49-62. http://dx.doi.org/10.1016/j.jdeveco.2009.04.006

Lipsey, R. E., Feenstra, R. C., Hahn, C. H., \& Hatsopoulos, G. N. (1999). The role of foreign direct investment in international capital flows. In M. Feldstein (Ed.), International capital flows (pp. 307-362). Chicago: University of Chicago Press. Retrieved from http://www.nber.org/chapters/c9801

Mataloni, R. J. (1995). A Guide to BEA Statistics on U.S. Multinational Companies. Survey of Current Business, 75(3), 38-55. Retrieved from http://www.bea.gov/scb/pdf/internat/usinvest/1995/0395iid.pdf

Moncada-Paternò-Castello, P., Vivarelli, M., \& Voigt, P. (2011). Drivers and impacts in the globalization of corporate R\&D: An introduction based on the European experience. IZA Discussion Papers, No. 5582. Retrieved from http://ftp.iza.org/dp5582.pdf

Montresor, S., \& Vezzani, A. (n. d.). On the R\&D giants' shoulders: Do FDI help to stand on them? Economia e Politica Industriale, 42(1), 33-60. http://dx.doi.org/10.1007/s40812-014-0002-1

Motohashi, K. (2015). Global business strategy: Multinational corporations venturing into emerging Markets. Springer Texts in Business and Economics.

Mudambi, R., \& Mudambi, S. M. (2005). Multinational enterprise knowledge flows: The effect of government inward investment policy. Management International Review, 45(2), 155-178. Retrieved from http://www.jstor.org/stable/40836137

Naghavi, A., \& Ottaviano, G. (2009). Offshoring and product innovation. Economic Theory, 38(3), 517-532. http://dx.doi.org/10.1007/s00199-007-0322-8

North, D. C. (1991). Institutions. Journal of Economic Perspectives, 5(1), 97-112. Retrieved from 
http://www.jstor.org/stable/1942704

Patel, P., \& Vega, M. (1999). Patterns of internationalization of corporate technology: Location versus home country advantages. Research Policy, 28(2-3), 148-155. http://dx.doi.org/10.1016/S0048-7333(98)00117-6

Penner-Hahn, J., \& Shaver, J. M. (2005). Does international research and development increase patent output? An analysis of Japanese pharmaceutical firms. Strategic Management Journal, 26(2), 121-140. http://dx.doi.org/10.1002/smj.436

Qu, Z., Huang, C., Zhang, M., \& Zhao, Y. (2013). R\&D offshoring, technology learning and R\&D efforts of host country firms in emerging economies. Research Policy, 42(2), 502-516. http://dx.doi.org/10.1016/j.respol.2012.07.001

Roodman, D. M. (2009). How to do xtabond2: An introduction to difference and system GMM in Stata. The Stata Journal, 9(1), 86-136. $\quad$ Retrieved from http://www.cgdev.org/publication/how-do-xtabond2-introduction-difference-and-system-gmm-stata-workin g-paper-103

Roper, S., Du, J., \& Love, J. H. (2008). Modelling the innovation value chain. Research Policy, 37(6-7), 961-977. http://dx.doi.org/10.1016/j.respol.2008.04.005

Rugman, A., Verbeke, A., \& Yuan, W. (2011). Re-conceptualizing Bartlett and Ghoshal's classification of national subsidiary roles in the multinational enterprise. Journal of Management Studies, 48(2), 253-277. Retrieved from http://onlinelibrary.wiley.com/doi/10.1111/j.1467-6486.2010.00969.x/abstract

Saliola, F., \& Zanfei, A. (2009). Multinational firms, global value chains and the organisation of knowledge $\begin{array}{llll}\text { transfer. } & \text { Research } & \text { Policy, } & 389(2),\end{array}$ http://dx.doi.org.dbgw.lis.curtin.edu.au/10.1016/j.respol.2008.11.003

Shimizutani, S., \& Todo, Y. (2007). What determines overseas R\&D activities? The case of Japanese multinational firms. Research Policy, 37(3), 530-544. http://dx.doi.org/10.1016/j.respol.2007.11.010

Tebaldi, E., \& Elmslie, B. (2008). Institutions, Innovation and Economic Growth. Journal of Economic Development, 33(2), 27-54. Retrieved from http://www.jstor.org/stable/117150

United Nation Conference of Trade and Development. (2005). World investment report: Transnational corporations and the internationalization of $R \& \mathrm{D}$. Geneva. Retrieved from http://www.sciencedirect.com/science/article/pii/S0969593106000849

Von Zedtwitz, M., \& Gassmann, O. (2002). Market versus technology drive in R\&D internationalization: Four different patterns of managing research and development. Research Policy, 31(4), 569-588. http://dx.doi.org/10.1016/S0048-7333(01)00125-1

Wooldridge, J. M. (2002). Econometric analysis of cross section and panel data. Cambridge, Massachusetts: The MIT Press.

World Intellectual Property Organization. (2011). World Intellectual Property Report 2011. Retrieved from http://www.wipo.int/econ_stat/en/economics/wipr/

Zanatta, M., Costa, I., \& Filippov, S. (2006). Foreign direct investment: Key issues for promotion agencies. United Nations University Policy Brief, No. 10. Retrieved from http://collections.unu.edu/eserv/UNU:899/unu_pb_2006_10.pdf

Zhao, W., \& Liu, L. (2008). Outward direct investment and R\&D spillovers: The China's case. Conference proceeding of "Emerging Multinationals": Outward foreign direct investment from emerging and developing economies, October, 2008. Retrieved from http://gdex.dk/ofdi/55\%20Zhao\%20Wei.pdf

\section{Notes}

Note 1. These 23 countries are: Australia, Austria, Belgium, Canada, Czech Republic, Finland, France, Germany, Greece, Hungary, Ireland, Italy, Japan, Korea, Mexico, Netherlands, New Zealand, Norway, Poland, Portugal, Spain, Switzerland and United Kingdom.

Note 2. This point can be seen from Table 4 where values of R\&D intensity by U.S.-based MNEs in various industries, countries and years are presented.

Although not shown in this paper, the R\&D intensity data calculated from the ANBERD database also show wide variation across different industries. 
Note 3. In this industry-level study, the share of sales in industry $i$ of country $j$ in global sales in industry $i$ is used to measure the relative market size of industry $i$ of country $j$. In contrast, in a country-level study, the share of sales in country $j$ in global sales will be used to measure the relative market size of country $j$.

Note 4. Chain-linked measures are suitable for comparison across countries and time.

Note 5. It is possible that R\&D intensity of the affiliate may in turn influence the sales in the industry of the host country and the FDI stock there as well.

Note 6. The minimum value of the legal structure and property rights sub-indicator appears in Mexico in 2001. The minimum value of the overall institutional quality measure appears in Poland in 2001. The second smallest value of the overall institutional quality measure appears in Mexico and Poland in 2001 and 2000 respectively.

Note 7. The coefficients of host country industry R\&D intensity, market share of host country and number of researchers per thousand population are significant at the $10 \%, 1 \%$ and $1 \%$ level respectively.

\section{Copyrights}

Copyright for this article is retained by the author(s), with first publication rights granted to the journal.

This is an open-access article distributed under the terms and conditions of the Creative Commons Attribution license (http://creativecommons.org/licenses/by/3.0/). 